\title{
Bees, farmers, tourists and hunters: conflict dynamics around Western Tanzania protected areas
}

\author{
Yves Hausser · Helene Weber · Britta Meyer
}

Received: 22 December 2008/Accepted: 13 May 2009/Published online: 4 June 2009

(C) Springer Science+Business Media B.V. 2009

\begin{abstract}
Following important donor funding in Tanzania since the 1990s to support community based natural resource management, several cooperation agencies have implemented projects aiming at developing innovative conservation strategies combining protected and sustainable use areas. Based on data gathered in the Katavi Rukwa Lukwati and Ugalla core areas of Western Tanzania, this paper compares and analyses how projects developed their strategy and objectives to address conflicts between local population and conservation agents, and how this led to changes in conservation practices. The projects managed to achieve their objectives in conservation and poverty reduction at various degrees. Enhanced conflict resolution capacity involving private stakeholders, conservation agents and local communities, as well as improved collaboration between projects, helped to solve part of the conflicts. This was the case with the negotiation of rights of access for beekeepers to Rukwa game reserve. However, enduring sector based approaches continue to hinder opportunities for developing multiple use approaches. Contrasted results of the projects can be explained by factors inherent to projects' planning and management, but also by factors that are beyond projects' influence such as the historical and contemporary context in terms of governance of natural resources and more globally, of power relationships between the state, private organisations and the communities.
\end{abstract}

Keywords Community based natural resource management - Decentralisation · Donor projects · Conflicts · Tanzania

\footnotetext{
Y. Hausser $(\bowtie) \cdot H$. Weber

Natural Resource Management Department, University of Applied Sciences of Western Switzerland, 150 route de Presinge, 1254 Lullier, Jussy, Geneva, Switzerland

e-mail: yves.hausser@hesge.ch

Y. Hausser

Association for the Development of Protected Areas, Geneva, Switzerland

B. Meyer

Tanzanian NGO "Friends of Katavi", Munich, Germany
} 


$\begin{array}{ll}\text { Abbreviations } \\ \text { ADAP } & \text { Association pour le Développement des Aires Protégées, Swiss internat. NGO } \\ \text { CBNRM } & \text { Community based natural resource management } \\ \text { CBO } & \text { Community based organisation } \\ \text { IBDSP } & \text { Inyonga beekeeping development support programme } \\ \text { KfW } & \text { Kreditanstalt für wiederaufbau - German development bank } \\ \text { KRCD } & \text { Katavi Rukwa conservation and development programme } \\ \text { SUA } & \text { Sokoine university of agriculture } \\ \text { TANAPA } & \text { Tanzania national parks } \\ \text { TAWIRI } & \text { Tanzania wildlife research institute } \\ \text { UASWS } & \text { University of applied sciences of Western Switzerland } \\ \text { UCLCP } & \text { Ugalla community landscape conservation programme }\end{array}$

\section{Introduction}

Community based natural resource management (CBNRM) approaches have been mainstreamed in the last two decades as an important component of conservation strategies and policies worldwide. This approach to conservation can be understood as the "principles and practices that argue that conservation goals should be pursued by strategies that emphasize the role of local residents in decision making about natural resources" (Adams and Hulme 2001). The rationale behind it is to create local incentives for sustainable resource management through devolved rights to manage and control benefits. CBNRM is inherently a process of negotiation over resource rights and access among multiple users and interests. Sayer and Campbell (2004) defined CBNRM as "the integrated management of a multitude of open access, common property and privately owned natural resources at the community scale". As underlined by Agrawal and Gibson (1999), "communities are now the locust of conservation thinking". This movement followed what has been called "a paradigm shift" in conservation (Balasinorwala et al. 2004), which gives a growing recognition to the social impact of conservation strategies (West et al. 2006).

However, in parallel to the continuous extension of strictly protected areas internationally, areas excluding human beings (IUCN categories I and II) remain the main conservation strategy (Adams and Hutton 2007), and CBNRM projects have been developed mostly in buffer zones (IUCN categories IV-VI). These latter projects were supposed to contribute to a better coverage of biodiversity conservation through the inclusion of important corridors and dispersal areas, while compensating for costs incurred by communities and therefore reducing the level of conflicts in these areas.

Even in a country like Tanzania, which went far beyond the $10 \%$ target of protected area establishment, most of biodiversity is to be found outside the network of strictly protected areas. The challenges are thus definitely on areas outside strictly protected areas' networks, which implies a negotiating process between stakeholders representing local livelihoods on one side and biodiversity conservation on the other side.

The donor community has supported the development of numerous CBNRM projects and programmes by a growing number of organisations. Projects remain the most important tool of the conservation and development support to developing countries. They channel an important amount of funding, despite important criticism regarding their ability to reach both conservation and development objectives and despite questions regarding their cultural appropriateness to varying local contexts. 
In Tanzania, donor support to CBNRM has burgeoned during the 1990s and early 2000s (Nelson et al. 2007; Jambiya et al. 2000 Alcorn et al. 2002). These projects were developed mostly under sector based approaches in wildlife and forest management. The evaluation of these projects focused mostly on a limited number of "success stories" located in the Northern and Southern areas and none included assessment of experiences implemented in Western Tanzania. Most of the research implemented in the area restricted the analysis to ecological factors, without integrating political aspects. Political ecology insights needed for questioning the outcomes and sustainability of the strategies implemented were ignored. According to Adams and Hutton (2007:149), "political ecology attempts to link an understanding of the logics, dynamics and patterns of economic change, the politics of environmental action and ecological outcomes, a set of relationships fundamental to conservation."

The CBNRM trend brings a renewed interest for the study and management of low ${ }^{1}$ status protected areas-multiple use areas-that frequently serve as buffer zones of strictly protected areas. Recent studies have revealed the high biodiversity value of these areas, showing that they serve not only as dispersal areas and corridors for parks and reserves, but equally host distinct communities of species (Gardner et al. 2007; Fitzherbert et al. 2006).

The aim of this paper is to document CBNRM experiences in Western Tanzania, with a particular focus on the role of CBNRM projects in conflict management and resolution. This will be done through the analysis of three donor support projects that were developed in and around the core area of two complexes of protected areas, Katavi-Rukwa and Ugalla.

We will thus (1) briefly present the territories and associated populations, (2) describe the type of conflicts present in the area and analyse the history with respect to the evolution of the conflicts, (3) assess how CBNRM projects attempted to address these conflicts, and (4) discuss the determining factors for success and failures of projects activities which address conflicts. Finally, we will conclude with suggestions about what projects should consider in the future in order to properly address conflicts.

\section{Materials and methods}

The present paper is based on data gathered through a research project called "Participation in the management of natural resource: the role of communities", implemented from 2005 to 2007 by the University of Applied Sciences of Western Switzerland (UASWS), in collaboration with the Tanzania Wildlife Research Institute (TAWIRI) and Sokoine University of Agriculture (SUA). The research project facilitated six UASWS Bachelor internships and one SUA master field study, totalling 24 months of field studies on natural resource management under various land tenure conditions.

We reviewed published and grey literature, particularly working documents published by different projects, reports and evaluations, and local government records pertaining to natural resource users.

Field data collection used standardized questionnaires addressed to local communities to assess local socio-economic conditions. More than 200 questionnaires were used in 12 villages of Inyonga division, and 100 in 8 villages of Ipole and Urambo Divisions, Tabora region. These questionnaires helped us to collect the communities' point of views about

1 The term "Low status" refers to the IUCN category system, without taking into account effectiveness of conservation. 
conservation policies and practices, impacts on livelihoods and projects' action. It supported the understanding of their representation of conflicts and project's intervention in conflictive context.

We used as well semi directed interviews with key resource persons involved in natural resource management in the study area. We interviewed six project staffs, six districts natural resource officers, and three trophy hunting companies' staff, 18 village game scouts and 20 community representatives involved in Community Based Organisation (CBO).

In the attempt to analyse projects' outcomes and impacts pertaining to conflict resolution, we used PCIA (Peace and Conflict Impact Assessment) as a framework. Though the method is still under development and subject to numerous criticisms (see Hoffmann 2003; Austin et al. 2003), it offers a substantial support to the analysis. It helps to frame analysis under various key-questions in an attempt to examine underlying assumptions of the models. The PCIA gives particular importance to the context of interventions. According to Bush (1998), when applying the PCIA to projects ex-post evaluation, we have to focus on the following points:

- Did the project produce substantial or politically significant changes in access to individual or collective material and non material resources?

- Did the project create, exacerbate or mitigate socio-economic tensions?

- Did the project produce substantial changes in the material basis of economic sustenance or food security?

- Did the project produce challenges to or changes in content of or control over existing political, economic and/or social systems?

When reviewing projects answers to conflicts, we did thus apply these questions to the project's actions to evaluate their impacts on existing conflicts.

Based on the data, we induced a grounded typology of conflicts. We have then analysed these conflicts in the light of the history of conservation considering its impacts on local communities. Finally we applied the PCIA framework as developed by Bush (1998) to understand project's impacts on the various conflicts identified in the course of the project. As none of the projects was especially designed as a conflict mitigation process, and in the absence of any element in the logical frameworks of the projects relative to conflicts, the PCIA approach appears the most adapted to try to identify conflicts elements in the strategy and potential impacts of projects interventions. Traditional donor evaluation would be inefficient to identify unintended impacts as it only builds on a priori and predetermined set of indicators to measure results of the projects (Hoffmann 2003).

Lastly, and this is probably the most difficult exercise, we tried to identify factors of successes and failures, bearing in mind that successes in a particular sector and in the view of a particular stakeholder might be judged as a failure in another sector or in the view of another stakeholder.

\section{Study area}

Our study area is part of the regions of Tabora and Rukwa in Western Tanzania. These regions contain some of the less disturbed ecosystems of the country, probably due to their remoteness, the low density of human populations and poor infrastructure. Most of the area is covered by the dry Zambezian miombo woodland ecosystem, dominated by trees of the Caesalpinioideae family adapted to long dry periods such as the genera Brachystegia, Julbernardia and Isoberlinia. The region experiences a bimodal rainfall, concentrated 

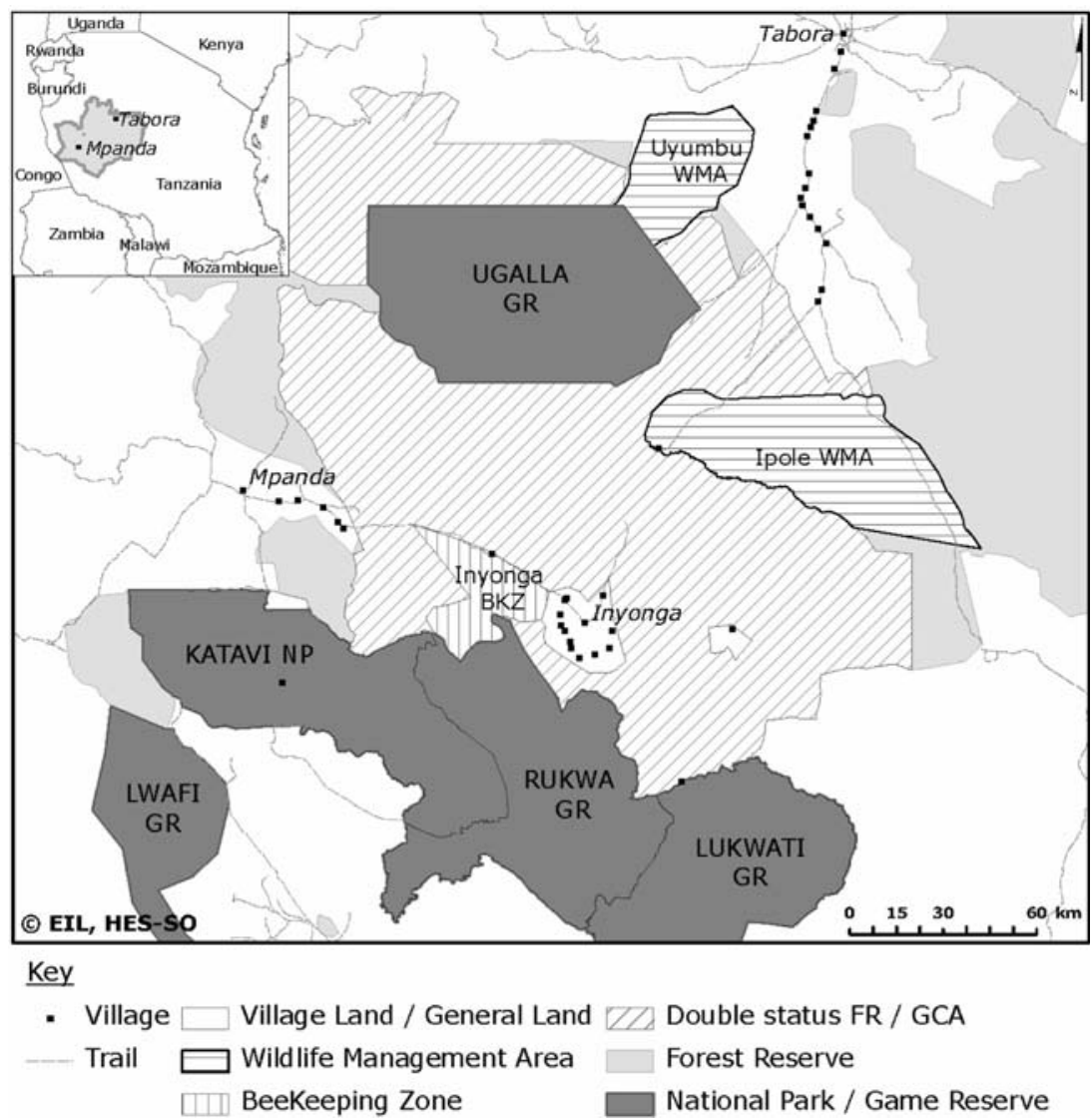

Fig 1 Map of the Katavi-Rukwa and Ugalla protected areas complex

between November and April. Temperatures range between 15 and $25^{\circ} \mathrm{C}$ and the area receives $900-1,200 \mathrm{~mm}$ rainfall annually.

An important part of this ecosystem falls under various forms of legal protection (Fig. 1), and are thus submitted to different management regimes involving different stakeholders (Table 1). The vast majority of these protected areas are allocated to private trophy hunting companies by the Wildlife Division. Photographic tourism is currently limited to Katavi national park and some village land bordering the park. The management of these areas and sectors is dispatched between many different organisations. This is a situation which leads to governance complexity and potential conflicts.

The area is still sparsely populated and local populations are relatively homogenous with regard to other regions of Tanzania, but this situation is changing rapidly with both natural growth and migrations. Population growth rate in Mpanda district exceeded 5\% per annum during the 1980s (Borgerhoff Mulder et al. 2007) and recent census confirmed a continued but slower growth over 3\% (National Census 2002). While Mpanda district covers more than $47,000 \mathrm{~km}^{2}$, the total population of the district was 410,452 according to the last national census, with over $80 \%$ living in rural areas $\left(8.7\right.$ people per $\left.\mathrm{km}^{2}\right)$. The situation is similar in Sikonge, Uyui and Urambo districts, in Tabora region. 
Table 1 Protected areas and management regimes in Tanzania

\begin{tabular}{|c|c|c|c|c|c|c|}
\hline \multirow[t]{2}{*}{ Protected areas } & \multicolumn{6}{|c|}{ Management institution } \\
\hline & $\begin{array}{l}\text { MNRT- } \\
\text { wildlife } \\
\text { division }\end{array}$ & $\begin{array}{l}\text { MNRT-forestry } \\
\text { and beekeeping } \\
\text { division }\end{array}$ & TANAPA & $\begin{array}{l}\text { District } \\
\text { council }\end{array}$ & $\begin{array}{l}\text { Village } \\
\text { council }\end{array}$ & $\begin{array}{l}\text { Community } \\
\text { based } \\
\text { organisation }\end{array}$ \\
\hline National parks & & & $*$ & & & \\
\hline Game reserves & $*$ & & & & & \\
\hline Forest reserves & & $*$ & & $*$ & $*$ & \\
\hline $\begin{array}{l}\text { Game controlled } \\
\text { areas }\end{array}$ & $*$ & & & $*$ & & \\
\hline $\begin{array}{l}\text { Wildlife management } \\
\text { areas }\end{array}$ & $*$ & & & $*$ & $*$ & $*$ \\
\hline Beekeeping zones & & $*$ & & $*$ & $*$ & $*$ \\
\hline Open areas & $*$ & & & $*$ & & \\
\hline
\end{tabular}

Resident populations are hunter-gatherers who turned in the mid twentieth Century to agriculture. Pimbwe, Konongo and Nyamwezi groups are, respectively found in Mpimbwe Division south of Katavi national park, Inyonga division, north east of the park, and Sikonge district, bordering Ugalla game reserve. These resident populations cohabit since about 25 years with a growing population of Sukuma migrant agro-pastoralists, who have been leaving the central part of Tanzania due to drought and increasingly difficult resource availability in water and pastures. Despite relying strongly on agriculture, local communities have maintained a high dependence on the direct use of natural resources. This is particularly marked during the dry season, when food insecurity is severe, and natural resources are needed as a food security net, particularly through hunting and harvesting of wild plants (Carpaneto and Fusari 2000; Borgerhoff Mulder et al. 2007). The extractive activities traditionally undertaken by local communities include hunting, selective logging, collection of non timber forest products (beekeeping, mushrooms, wild fruits and plants), and medicinal plants.

From a spatial point of view, as can be seen on Fig. 2, the available land for legal village based natural resource management activities is very limited. In Inyonga division approximately 22'000 villagers have access to $640 \mathrm{~km}^{2}$ of village land, while there are $13,050 \mathrm{~km}^{2}$ of protected areas (TANRIC 1995). As underlined by Borgerhoff Mulder et al. (2007), "indigenous villages and the belts of outlying Sukuma homesteads are increasingly surrounded by protected areas to which the people have no legal access." As a consequence, most of extractive activities by local communities become illegal through the law. Wildlife hunting is totally prohibited and timber and beekeeping extraction subject to permit system in the vast majority of the area.

Population is also increasing due to the effects of the Great Lakes' conflict. An important population of refugees from Burundi is established in Mpanda district, Katumba and Mishamo Refugee camps hold over 200,000 people (IRA 2005; Jambiya et al. 2007). Both camps are located in close distance to major protected areas like Ugalla or Katavi and the negative impacts on natural resources - forests and wildlife-have become an significant problem throughout the area (IRA 2005; Jambiya et al. 2007).

Threats to the ecosystem and the protected areas system include land conversion for agricultural development, particularly tobacco cultivation, illegal off-take of wildlife (self 


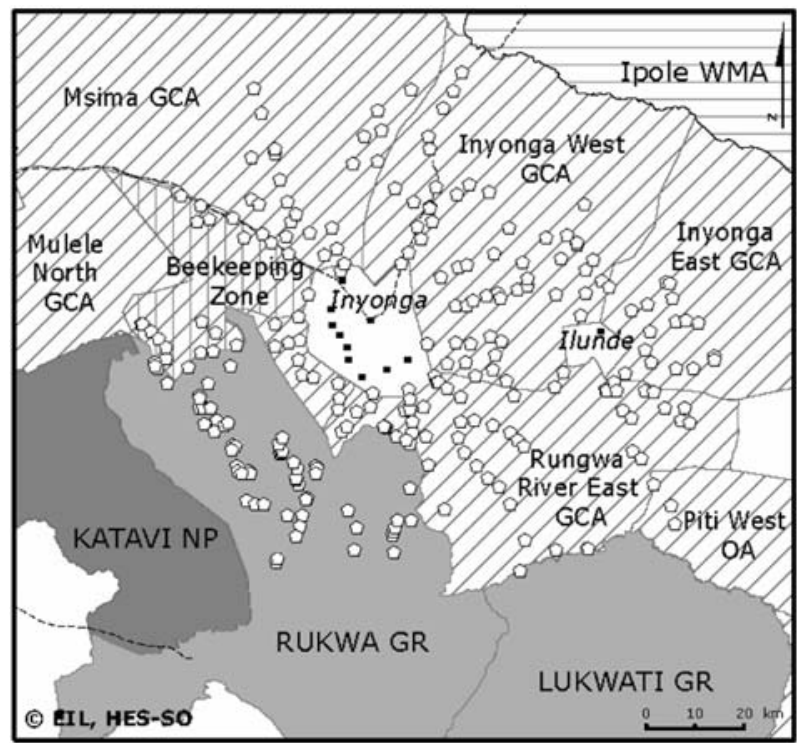

Key

- Village $\square$ Village Land / General Land $\square \square$ Game Controlled Area

- Beekeeping Camp प\| BeeKeeping Zone National Park

-.-.- Trail $\square$ Wildife Management Area $\square$ Game Reserve

Fig. 2 Spatial use of village based beekeeping in the forest reserves/game controlled areas and in Rukwa game reserve

consumption and commercial trade), illegal timbering, massive charcoal production, pesticides use in agriculture, perturbation of the hydrological system through mining and irrigation, and absence of fire management.

\section{Results}

Conflict is a common feature of natural resource management and conservation (Balmford et al. 2001), and generally arose from competing interests of various stakeholders in the use of the resources of a defined area. As underlined by Adams et al. (2003), conflicts do not solely rely on competitive material interests, but are more deeply representative of cognitive conflicts. Addressing the conflicts in natural resources can be done through five different strategies: avoidance, mediation, adjudication, negotiation, arbitration, or coercion (Matiru 2000). Different strategies are frequently combined in the attempts to solve conflicts.

\section{Conflicts present in study area}

Conflicts in the study area are mainly opposing local and exogenous stakeholders regarding competitive interests in the use of the resources of the area.

As represented in Table 2, we have identified seven major types of conflicts. They concern boundaries, access rights, user rights, regulation of illegal use, land use and management, benefit generation and human-wildlife conflicts. 


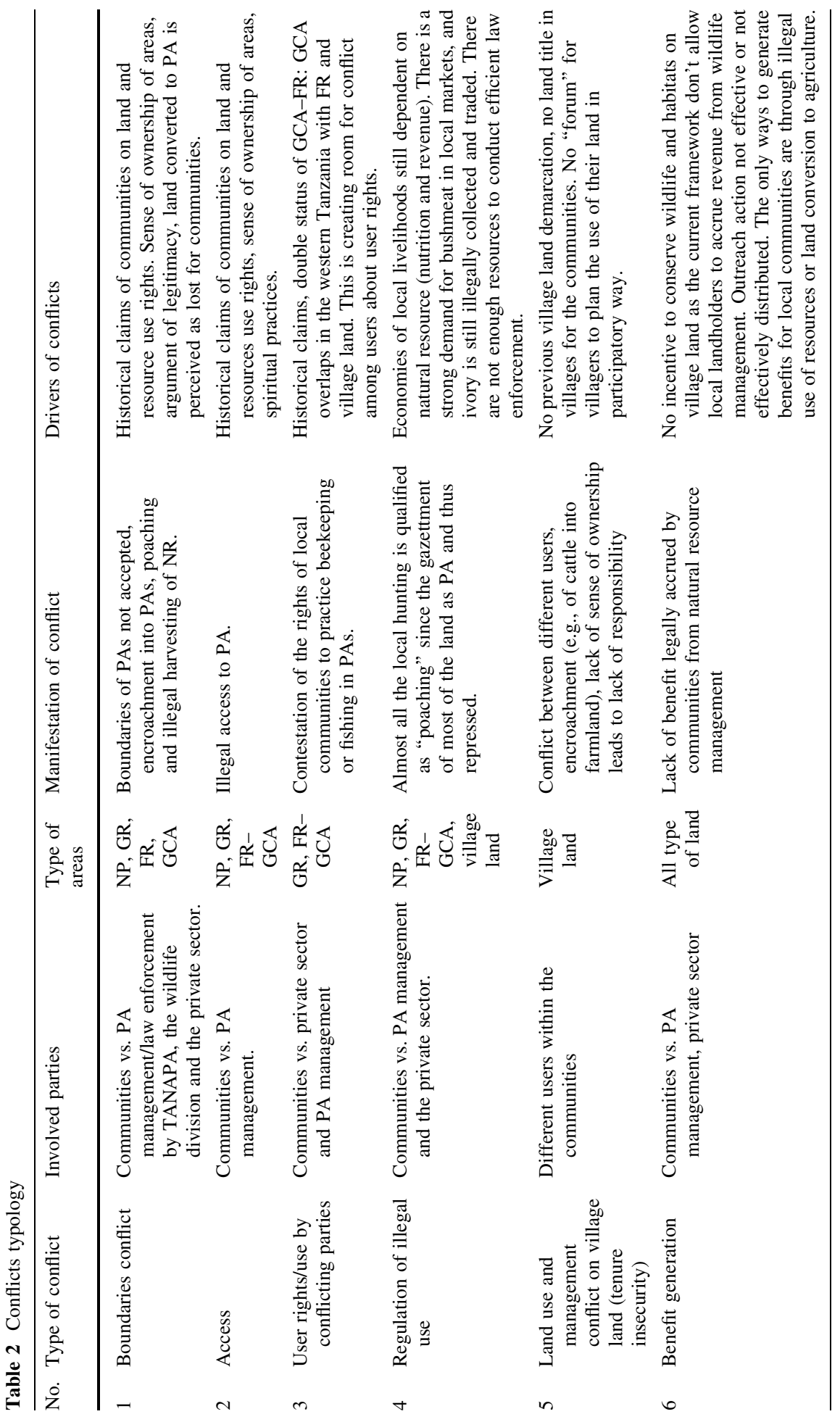




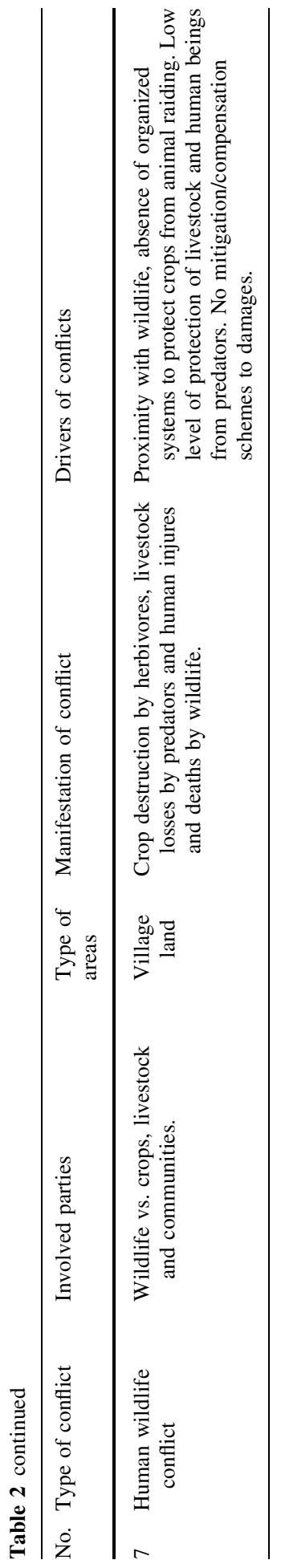


The seven described type of conflicts fall in three general categories. The first is linked to the issue of ownership, access and control of territories and to a narrative of loss developed by local communities towards conservation. It covers as well the question of inter-village boundary conflict and conflict between native and migrants regarding use rights of common pool resources like grassland, water resources and firewood.

The second refers to a major conflict between perceived incompatible uses, the trophy hunting and all local form of land use. The arguments developed to explain the incompatibility of the local forms of resource use with trophy hunting activity are numerous: security and risks associated to the hunting, contractual exclusivity, illegal removal of wildlife by local users under cover of other forms of use such as beekeeping (competition for the same resource), human presence affecting distribution of wildlife, uncontrolled bushfires, disturbance to the clients who paid to be in a wilderness area.

The third refers to the issue of the illegal use of resource in and outside protected areas. It represents the coercion strategy and is implemented through anti-poaching activities.

Most conflicts concern issues of rights of access to and use of natural areas and resources. The vast majority of conflicts oppose conservation agents and villagers during anti-poaching operations implemented by Tanzania National Parks (TANAPA), the Wildlife Division, the Districts and the trophy hunting companies. Spatially, most of these conflicts happen in the forest reserves/game controlled areas, which are double status areas (Ministry of Natural Resources and Tourism 2000; Hausser and Mpuya 2004). This status is creating room for conflicts, as it legitimates different stakeholders' claims regarding competitive forms of use. Figure 2 shows the status of the areas where beekeeping occurs, revealing potential conflicts between beekeeping and other forms of land use.

In most cases, the anti-poaching teams do contest villagers' access and/or user rights to surrounding forest areas, despite legal status allowing such forms of local use. Frequently, the different forms of local use of the forest are assimilated to poaching, in other words: "all villagers are poachers". These conflicts frequently ended up in symbolic (discourse) and physical violence, particularly directed to local villagers. Some of these conflicts ended up with a judiciary procedure.

The numerous conflicts identified in the course of our study were systematically linked with conflicting stakeholders' interests and differing values regarding landscape and resources. This is confirming the cognitive dimension of conflicts. Interestingly, every stakeholder claims its ownership and right of use of the concerned areas, based on arguments of legitimacy (customary use) or legality (modern legislation).

To understand this conflicting situation, it seems necessary to adopt an historical perspective since many conflicts take their roots in the recent history of conservation in the area.

\section{Historical background}

From an historical point of view, the development of a modern conservation strategy through the continuous extension of a protected area network has always been detrimental to local communities by increasingly reducing their rights of access to land and resources. This is particularly noticeable with the wildlife resource and the numerous evictions for conservation that occurred over time throughout the country (Nelson et al. 2007; Brockington and Igoe 2006; Brockington 2004; Neumann 1998). As it has been observed elsewhere in Africa (Adams 2004a, b; Roulet 2004), Nelson et al. (2007) noticed that the introduction of modern conservation policies implied a progressive criminalization of local hunting practices in early colonial times, before engaging into the creation of the first 
protected areas, where people have seen their rights of use being progressively reduced, and finally suppressed to be in the end forcefully resettled.

The post independence period was characterized by a perpetuation of colonial policies, with an upgrading of existing lightly protected areas into strictly protected areas, further reducing the rights of local communities. The adoption of the Wildlife Conservation Act of 1974 "continued and intensified the colonial practices of restricting local wildlife use and consolidating state authority" (Nelson et al. 2007). Since the adoption of the act, there has been a continuous movement towards increasing the coverage and towards an upgrading of the status of the protected area (Walsh 2006; Brockington and Igoe 2006; Neumann 1998).

This situation of centrally and exclusively managed extensive protected areas led to the crisis of the 1970 and 1980s, which witnessed a drastic fall in wildlife populations, and the state being not able to enforce its policies. This was the rationale for introducing a reform in the mid 1990s, with a strong support from international conservation organisations and bilateral cooperation agencies, through the funding of pilot CBNRM projects and reform processes. As Nelson et al. (2007) clearly showed there has been opposite moves with the development of a strong pro CBNRM narrative and the adoption of pro CBNRM policies on the one hand, and the on going policy of strictly protected areas extension that are centrally managed on the other hand. These sector reforms in natural resource management were combined with land reforms and local government (decentralisation) reforms. During the 1990s, the ongoing liberalization of the Tanzanian economy was considered as a promising environment for CBNRM development (Nelson et al. 2007; Alden-Wily 2001; Hausser and Mpuya 2004).

Considering the long term historical trend, the situation of the Western area changed dramatically between 1860 s and the early 1900s. Fairly well developed in comparison to other areas of the Tanganyika territory when the explorers first arrived, a combination of climatic, epidemiologic and politic factors reversed the region's development trend within two decades. Droughts, rinderpest, smallpox outbreaks and early indigenous policy of the German colony all contributed to affect the local subsistence and to depopulate the area (Borgerhoff Mulder et al. 2007; de Vries 2005). As summarized by de Vries regarding Tabora, "From surplus production in 1890, the province was on the verge of poverty in 1910" (de Vries 2005:43). The sleeping sickness outbreaks of the 1920s further aggravated the situation of the local population and led to a policy of village resettlement that affected most of the rural areas and opened up the way to the first important conservation actions.

The main driver of village relocation in the Western area has been the fight against sleeping sickness, both in Katavi-Rukwa area (Borgerhoff Mulder et al. 2007) and in the area of Ugalla (Brockington and Igoe 2006; de Vries 2005). Conservation planners have been particularly effective during the colonial and post colonial era. According to Baldus and Cauldwell (2004:7), 90 game controlled areas were gazetted countrywide in the 1950s as areas where hunting was prohibited or allowed only on a special request basis. It was the case of a vast Inyonga game controlled area that covered $9,000 \mathrm{~km}^{2}$, e.g., the whole of Inyonga division. The game controlled area status is offering only a limited protection as it restricts hunting but not settlement or the agriculture development. As underlined by Baldus and Cauldwell (2004:6),"the law makes, however, no restrictions on other forms of land use and local communities are allowed to permanently reside within a game controlled area". Most of the Western area was later gazetted as forest reserves. This status restricts human establishment and use, and the designed reserves were overlapping with existing game controlled areas. Some existing forest reserves were upgraded to game reserves. This has been the case for the creation of every game reserve in the Western area. 
In Western Tanzania, narrative of land alienation is still vivid among communities, particularly regarding the creation of the forest reserve network in the early 1960s (de Vries 2005), the recent extension of Katavi national park and the establishment of Rukwa and Lukwati game reserves in the mid-1990s (pers. obs. 2002-2007). Finally, it must be underlined that conservation efforts (e.g., anti-poaching patrols) have augmented during the past two decades, and that conflicts culminated during the 1990s and early 2000. This has led the local wildlife economy to enter definitely into illegality and bushmeat markets to develop under cover.

There was then an unbalanced situation with the communities bearing all the conservation costs, while benefiting in a limited manner from legal natural resource use.

Projects thus developed their activities in a conflictive context, as revealed by the number of complaints received at district level, particularly in Mpanda, and the numerous cases of violence toward villagers during anti-poaching patrols (Hausser and Mpuya 2004; Borgerhoff Mulder et al. 2007). Our interviews reveal that as a consequence, the projects were not perceived as "neutral" by the local stakeholders. Depending on the strategy developed by the projects, they were either categorized as pro- or anti-villagers.

How did the projects address the conflicts?

\section{Brief projects description}

Three projects have been developed by cooperation organisations in the area in the late 1990s. The three projects are the Katavi-Rukwa Conservation and Development Programme (KRCD), implemented by the Deutsche Gesellschaft für Technische Zusammenarbeit (GTZ), the German technical agency for cooperation; the Ugalla Landscape Community Conservation Programme (UCLCP), implemented by the international US based NGO AFRICARE; and the Inyonga Beekeeping Development Support Programme (IBDSP), implemented by a Swiss based international NGO, the Association for the Development of Protected Areas (ADAP). Obviously, most "community based" activities were implemented in the buffer zones of the strictly protected areas. Table 3 provides brief project profiles.

Despite being designed totally independently by institutions that vary in their missions, strategies, organisational structures, and culture, the three projects have numerous similarities, particularly in the way both problems and solutions were identified. Their diagnosis was quite similar regarding threats to conservation. They developed a common narrative for justifying their intervention, which can be summarized as "a great ecosystem under a growing pressure and deprived communities in deep need of help". A common narrative to the three projects is the threat represented by the extension of tobacco cultivation in Western Tanzania's Miombo woodlands.

Objectives were formulated in a similar manner:

KRCD: "the conservation of biodiversity and natural resources in Katavi-Rukwa, by enabling the people in the buffer zone to derive sustainable benefits from the ecosystem" (Mann 2007).

UCLCP: "to create a foundation for sustainable community based conservation and natural resource management in Ugalla ecosystem". The objective was reviewed in 2003, "to improve sustainable community based conservation of Uyumbu and Ipole wildlife management areas and natural resource management in Ugalla ecosystem" (Kajembe et al. 2004). 


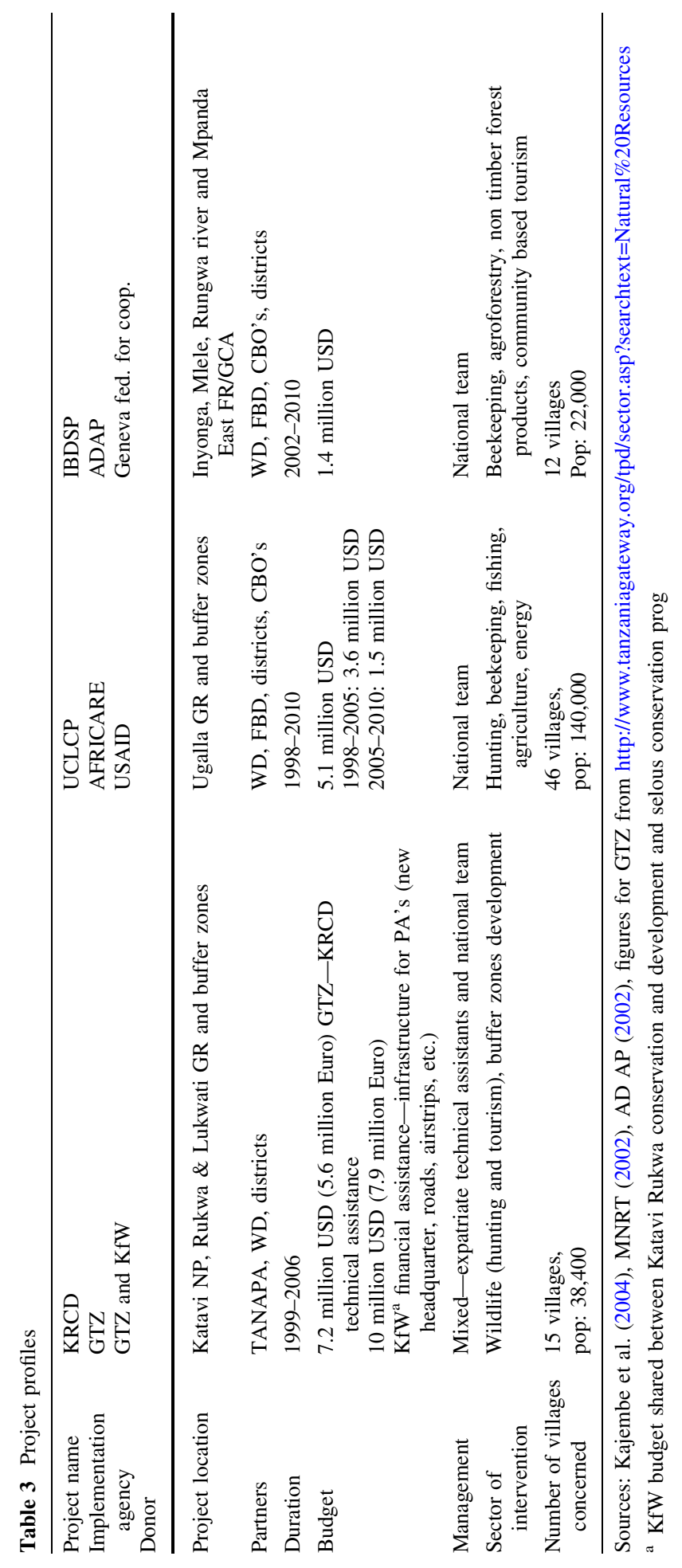


IBDSP: "support to the establishment of local institutional mechanisms ensuring participatory management of natural resources in Inyonga division and ensure an increase in the communities revenues derived from a sustainable use of natural resource" (ADAP 2002).

Projects were also sharing common strategic principles, such as the creation of community based use zones and local management institutions established through participatory processes. With a focus on strictly protected areas, KRCD planned to develop its community use component in the buffer zones of its core area, with the development of wildlife management areas. UCLCP explored the different possibilities offered by the legislations and supported the development of both wildlife management areas and village forest reserves. IBDSP explored the possibilities offered by the Beekeeping legislation and supported a beekeeping zone which can potentially become a community managed bee reserve. Except with UCLCP which embraces the full scope of opportunities offered by the sector based legislations, the sector based approaches offered little room for joint action between projects.

\section{Project's responses to conflicts}

It should be specified that none of the projects was especially designed to address conflicts. Despite the importance of conflicts being identified in early stages of the projects, they were not framed to specifically address them. The conflicts' resolution contribution has been integrated into holistic approaches aiming at solving both conservation and development problems. Projects' attempts aimed at reducing this inequity and re-equilibrating the cost and benefit balance of conservation between stakeholders at different spatial and institutional levels (Table 4).

What seems to have been determinant is the ability of projects to manage the conflicts in a constructive manner, (e.g., to turn problems into solutions). Most of the arguments to justify the incompatibility of trophy hunting and village forms of use have been addressed through negotiating processes and ended up with institutional arrangements between stakeholders.

\section{Boundaries conflict \& access and use: demarcation and land status and rights clarification}

As previously mentioned the extension of Katavi national park and Rukwa game reserve in the mid-1990s generated conflicts with local users from Inyonga division. The conflicts arose from contested borders on the field of the new limits of extended protected areas. Similar border conflicts happened in Ugalla with the establishment of wildlife management areas. The three projects supported a clear demarcation process and the establishment of physical boundaries such as beacons and panels. In the case of UCLCP, the project supported an arbitration process by the Ministry of Natural Resources and Tourism. This contributed to clarify both status and rights of access and use for communities to protected areas.

In most of the cases, the clarification and physical setting of boundaries of strictly protected areas did strengthen the role and power of conservation organisations versus local communities. In the latter case, the arbitration process supported by ULCLP contributed to give back some disputed land to the communities and thus contributed to strengthen the institutional capacity of communities to solve conflict in a non violent manner. 


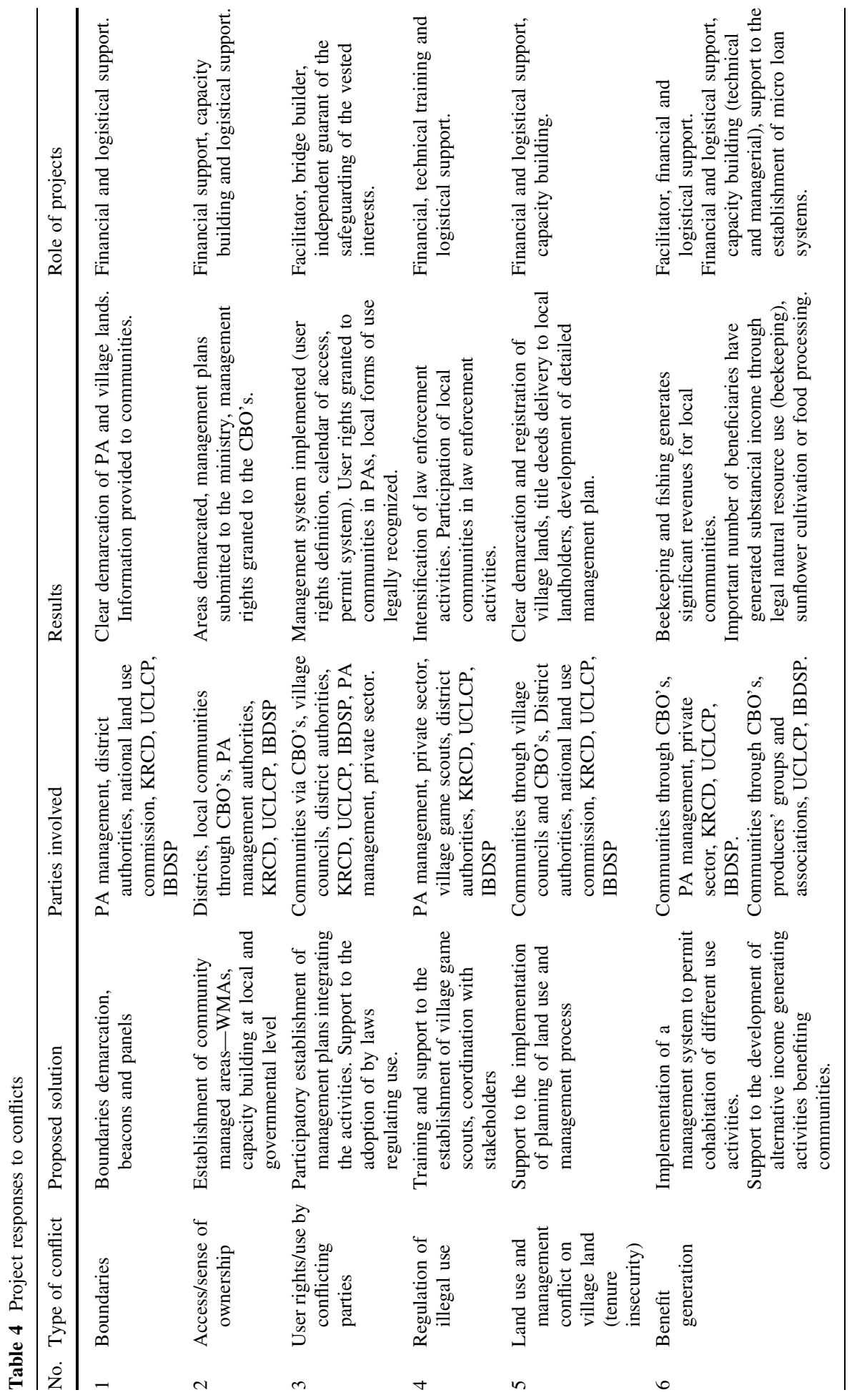


Permits to practice beekeeping in Ugalla and Rukwa game reserves

The permit system regarding beekeeping and forest use was already established in forest reserves. A first attempt to reintegrate beekeepers in a game reserve was successfully implemented in the end of 1990s in Ugalla. It has been replicated with success in Rukwa in the early 2000s. In both cases, a formal institutional agreement was developed that included the zoning of the beekeeping areas within the game reserve and the integration in the management of regulations regarding the practice of the activity. The management plan equally set up maximum levels of use. A permit system was developed under the authority of the Wildlife Division, which authorize the villagers to enter the game reserve to practice the beekeeping activity under specific conditions. At a more practical level a calendar of access was established in coordination with beekeepers, managers and the trophy hunting companies. Beekeepers' camps are GPS registered and their legal users recorded. The camps are regularly checked by anti-poaching teams.

These institutional arrangements were supported by technical measures such as the introduction of bee smokers to replace the use of fire for honey harvesting and to prevent bushfires, and the introduction of village based law enforcement activities with the village game scouts, in coordination with trophy hunting companies and the district.

In Rukwa, KRCD and IBDSP have had different but complementary roles in the mediation process between the divergent interests of the Wildlife Division and the local communities. KRCD supported the work of the Wildlife Division in the integration of the beekeeping and fishing activity in the game reserve through the establishment of regulations and granting of user rights to communities. IBDSP supported the local users in organizing themselves so as to have a clear and formal representation through a $\mathrm{CBO}$ in the process.

In these cases, the projects directly contributed to facilitate access to forest-basis resource for beekeeping - and to increase the contribution of beekeeping to local economies. They equally contributed to facilitate a long claimed access to land confiscated by conservation and thus indirectly contributed to mitigate conflicts. The projects contributed to empower local communities, leading to a formal recognition by state authorities of their associations as stakeholders.

\section{Establishment of community managed protected areas}

The establishment of community managed protected areas relies on sectoral legislation. Administrative processes for the establishment of community managed areas differ importantly between the forest and beekeeping sector and the wildlife sector. The latter is the most complicated - a process of 12 steps-and time and resources consuming, to such an extent that without significant external support it seems impossible for communities to establish wildlife management areas. For both sectors, the processes include at least the following steps: (1) a village assembly decision to create a community managed area, (2) a village assembly decision to create a $\mathrm{CBO}$, (3) the registration of the $\mathrm{CBO}$ at the Ministry of Home Affairs, (4) the government requests that the CBO develops land use and management plans submitted to survey and approval by the Ministry, (5) once the management plan is approved, user rights are granted to CBO's.

The KRCD supported the establishment of Mpimbwe and Kabende wildlife management areas in northern and southern buffer zones of Katavi national park covering an estimated area of 3'400 $\mathrm{km}^{2}$. It supported the establishment of the CBO's, the training of 170 community members to allow them to manage the $\mathrm{CBO}$ and the area establishment 
process. The first steps have been successfully realized, but the process seems stalled since the end of the support from KRCD in December 2006. The CBO's are still waiting their authorization association status (step 8) from the Director of Wildlife to further continue the process.

IBDSP supported the development of a beekeeping zone of $900 \mathrm{~km}^{2}$ within Mlele forest reserve bordering Katavi and managed by Inyonga Beekeepers Association. The management plan has been transmitted to the Ministry for approval and a first letter of intent to transfer the management rights to the $\mathrm{CBO}$ was sent to Inyonga Beekeepers Associations by the Ministry. The IBDSP supported technical and managerial training to CBO's members and to 20 village game scouts.

ULCLP supported the realization of Uyumbo and Ipole wildlife management areas and various village land forest reserves, covering an estimated 6' $800 \mathrm{~km}^{2}$. UCLCP supported the establishment of the $\mathrm{CBO}$, registration, natural resource inventory and management plans conception and validation processes till their gazettment. The wildlife management areas were among the first of the country to have received their authorized association status (step 8), which authorizes the CBO's managing the area to enter into joint venture with private partner such as trophy hunting. The UCLCP project supported the training of 250 village game scouts to patrol the wildlife management areas. These two pilot areas, though advanced, have not yet reached the final stage of the process and are still waiting to be granted user rights.

This represents the most global attempt to solve all the conflicts in a combined manner. By granting not only user but management rights to CBO's representing local usersincluding rights to control access and use, the conception of use regulations (village by laws), the collection of fees and penalties, the generation of benefits from natural resource use through activities like beekeeping and fishing, the process aims at solving almost every conflict. It directly contributed to reduce the conflicts with conservation agents through a necessarily close collaboration for the establishment of these areas.

\section{Planning of land use management}

KRCD supported planning of land use management in the villages participating in the wildlife management areas. The project equally supported 32 villages in demarcating and getting the title deeds for their village land.

UCLCP and IBDSP supported in an significant manner the planning of land use management process in the villages. This process helps to solve conflicts on land tenure and use, and ensures some tenure security to villagers by delivering land titles' deeds. It can help to limit somehow the extension of tobacco cultivation and to favour conservation of forested areas in the village lands. The process has been implemented in the 12 villages covered by IBDSP in Mpanda districts and is still ongoing in the villages covered by UCLCP. IBDSP, in collaboration with Mpanda District Council is supporting the process until the building and launching of land registry offices at ward level in Inyonga division. The process is conducted from Division to village level, through Sector Based Detailed Management Plans. In each village, land has been set aside as village forest or bee reserves.

By supporting these processes the projects directly contributed to secure land ownership to local communities, solving a long lasting crisis. In the same time, it directly contributed to solve existing conflicts about village land boundaries and type of use, bringing together the various local users groups such as farmers and cattle breeders so as to plan together the use of land by safeguarding the interests of the different parties. In terms of sustainability, it is from communities' point of view, the most sustainable activity undertaken by projects. 


\section{Income generating activities benefiting communities}

Beekeeping UCLCP and IBDSP invested importantly in the promotion of alternative economic activities benefitting local communities. Among the targeted environmental friendly activities, beekeeping was leading in the two projects. In 2004, UCLCP recorded about 50 tons of honey produced per year, the same year, IBDSP recorded a production over 200 tons of honey in Inyonga division. In ULCLP, training in honey and wax processing benefited to 1,700 beekeepers. The project encouraged local manufacturers to produce ram presses, top bar hives locally.

IBDSP offered various training in collaboration with the Tabora station of Tanzania Wildlife Research Institute (TAWIRI) and Small Industries Development Organisation (SIDO). About 3,000 beekeepers benefited from training in Inyonga division regarding honey and wax processing, modern beekeeping techniques, introduction of modern hives, bee products packaging, quality honey making and marketing. Training are repeated on a regular basis, and benefit to both experimented and beginning beekeepers. Specific trainings were offered to carpenters and tailors to ensure the local production of modern beehives, beehouses, beesmokers and protective gears. IBDSP supported the development of Inyonga Beekeepers Association, with about 500 members in 2008. Annual production estimates vary from 80 tons to over 200 tons, depending on a diverse array of factors, including cyclical natural honey production. Average yearly global financial income from beekeeping in Mpanda district is estimated between 80'000 and 120'000 USD.

The support to alternative income generating activities like beekeeping contributed to re-equilibrate the cost and benefit balance of conservation in favour of communities. It directly contributed to reduce the dependency of communities to direct use (most of the time illegal) of natural resources and contributed to reduce the food insecurity at the local level. In the same time, non beekeepers members of communities complained that only beekeepers have seen their situation improved, while they only represents $20 \%$ of the local population. In this sense the projects contributed to generate jealousy and created new socio-economic tensions between beekeepers and other members of the local communities. The technical support to improve both quality and quantity of bee products positively impacted the material basis of economic sustenance of beekeepers, but equally strengthened the perceived favouritism towards beekeeping.

Cash crop alternatives UCLCP introduced cash crop alternatives, such as sunflowers, moringa, oil palm and fish farming. Training benefited more than 4,000 community members. Estimated cumulative incomes for 7 years vary from 5'683 USD/per household for beekeeping to $524 \mathrm{USD} /$ per household for fish farming and $276 \mathrm{USD} /$ per household from Sunflower cultivation.

IBDSP in association with International Centre for Research in Agro Forestry and Tumbi Agricultural Research Institute supported the introduction of agroforestry practices and sunflower cultivation. The same institutions provided women's group with training in food processing from wild products (jam, juice and wine processing) and training for soap production. IBDSP supported training in marketing and packaging of products, and for 4 years is supporting group members' participation in national and regional fairs. This has proven to be among the most efficient means to find markets for products.

Considering all these income generating activities, it can be underlined that both UCLCP and IBDSP lack proper recording systems that would permit precise estimates of incomes at household levels. 
The cash crop alternatives, while taking into account the non-beekeeping members of the communities, did raise fewer results for a variety of reasons, among them the less regular support provided to local groups compared to beekeeping. It did, however, contribute to reducing the dependency from direct resource use for a limited number of farmers and women's groups within the communities.

\section{Increase access to financial services}

Recognising lack of financial capital as being a major constraint to communities in their effort to shift to environmental friendly activities such as beekeeping or sunflower cultivation, both UCLCP and IBDSP supported the introduction of micro-loans. Initially focused on beekeeping materials, IBDSP expanded the coverage of its micro loan system to other sectors such as environmental friendly agriculture. The two projects are now establishing Saving and Credits Cooperatives (SACCO) for community members.

In a preliminary phase, IBDSP supported only beekeepers with micro-loans, this contributed to the generation of socio-economic tensions with other segments of the community. This was the rationale to extend the system to the entire local population, with a condition of supporting environmental friendly forms of use.

\section{Discussion}

The three projects implemented in Western Tanzania have reached at various levels their objectives in conservation and community development. We will now try to identify the factors of success and failure of these CBNRM projects in their attempts to contribute to conflict resolution. As underlined by Austin et al. (2003) the measure of success and failure is complicated and difficult to investigate. In our view, the best way to identify success and failures is through the multiple lenses of the various stakeholders involved in project management and implementation, with a particular attention to the views of communities. It will probably bring a nuanced and contrasted vision, rather than a clear answer, but would provide elements for reconciling conflicting interests and perceptions between stakeholders.

Problems with measuring the success or failures

First a success in one sector-such as in environmental conservation-might not equal to a success in conflict mitigation. Second, a success in the understanding of the implementation agency might not be perceived by project recipient as a success. This underlines the need to go back to the rationale underlying the project's conceptions when looking at the various results reached by the projects. The three projects, despite a common rhetoric regarding communities and conservation were having different rationales and entry points. While projects were conceived as integrated conservation and development projects, two of them, the KRCD and UCLCP projects were indirectly linked with the former extension of areas that were strictly protected and a had the objectives of strengthening the management of these areas. ${ }^{2}$ Thus they were founded to address existing conflicts, but actually

\footnotetext{
${ }^{2}$ Katavi national park was doubled in size, as was Rukwa game reserve in 1997. Lukwati game reserve was established in 1998. The KRCD project started in 1999. Ugalla game reserve management was reorganised in 1995 and the UCLCP started in 1998.
} 
participated in the perpetuation of these conflicts, taking into account the historical context. Because they focused on strictly protected areas, these two projects were relying on a strong conservation rationale.

This is further complicated by the fact that most of the time, the design of projects with the classical logical frameworks do not propose satisfying indicator for measuring success in a multiple realities context (Bush 1998). Rather, they do represent the view of the donor and the implementation agencies instead of the ones of the recipients or so called "beneficiaries". Most of them are quantitative-while quantitative data hardly help to measure changes in power relationships and mentalities. And even when they are supposed to reflect really measurable impact such as the size of land under increased protection, they rarely provide information about effectiveness of management. The qualitative indicators, when they exist are generally formulated in a vague and generic way.

Regarding the design of projects, KRCD and UCLCP were designed and implemented with a top-down approach involving foreign experts and government representatives. The fact that their financing was coming from bilateral cooperation institutions and was part of a greater and more global agreement between governments partially explains this design. In contrast, IBDSP financing comes from more decentralized bodies, and the NGO has associated to the design not only the government representatives, but also other concerned stakeholders, with a particular focus on the beneficiaries.

Budgets of the projects vary greatly in importance and patterns of allocation. This is partially explained by specificity of the project's design (e.g., the number of human resources and vehicles required, presence of expatriates). When looking at budget allocation, the KRCD devoted a very important part of its budget, the KfW contribution, to the building of management infrastructures. UCLCP invested also substantially, though to a more limited extent in the rehabilitation and the construction of management infrastructures for Ugalla wildlife division staff. By comparison IBDSP did not invest in governmental support but rather focused a major part of its investment in capacity building at community level, thus contributing to increase the social capital of community stakeholders.

CBNRM approaches as negotiation processes over access to natural resource are meant to contributing to conflict mitigation. CBNRM are per definition long term processes, and the design of the projects aimed at reaching measurable results on a relatively brief period of time are simply in contradiction with the nature of these processes.

The absence of sufficient baseline studies concerning both ecological and socio-economic data in the three projects (Kajembe et al. 2004; de Vries 2005) partially explains the difficulties to measure success and failures. Projects have indeed problems to record their results and thus to monitor and measure changes, particularly in resource conditions. Only KRCD supported the development of an ecological monitoring programme from the early stage of the project. None of the projects has achieved the final stage of developing ecological monitoring systems for the community managed areas, where the need of monitoring would be greatest.

For the donors and implementation agencies, the underlying hypothesis and assumptions of the CBNRM approaches are that once the local communities will benefit legally from natural resource use, they will reduce their level of illegal use of resources. If the famous "turning poachers to protectors" seems an attractive hypothesis, the reality in the field shows that this is rarely the case. Reasons are numerous, among them the fact that the projects' initiators rarely consult the beneficiaries about the desired outcomes of the project. Actually these desired outcomes are seldom an improved state of conservation of resources. In our cases, the increased production of honey and subsequent increase of 
revenue generated from beekeeping did not mechanically lead to a decrease of illegal use, and this for different reasons. First, as underlined previously, the beekeepers only constitute $20 \%$ of the communities. Second, even among the beekeepers, some have invested their income into other activities, such as tobacco growing, which are very destructive to the environment. If this could be criticized in the view of the implementation agency, this is just a rational strategy to diversify in order to diminish risk.

From a community point of view, the success of the project's interventions is clearly linked with their ability to mitigate the various types of conflicts local communities tend to experience when confronted with conservation projects and programmes (Table 2). In this respect, the support to planning land uses has play a key role because it has contributed to secure land rights of communities. The support to alternatives income generating activities that directly benefit local communities appears equally as an important factor of success. This contributes to re-equilibrate the cost and benefit balance of conservation. IBDSP and UCLCP did invest heavily on that side, whereas KRCD did not develop such a component. At the same level, the flexibility of projects in being able to adapt and modify their plans, and particularly to adapt for supporting local initiatives, appears like a major factor. Big top-down projects seems barely able to adapt to unanticipated situations. This stresses out the need of adaptive and flexible approaches.

Another factor influencing the success or failure of a project in managing conflicts management from a community point of view is the type of relationships developed between villagers and conservation agents. In KRCD and UCLCP, the close contact between the project's agents and the Wildlife Division and TANAPA was perceived by villagers as a collusion of interests. By contrast, IBDSP collaborated more with villagers and local governments, and was thus more perceived as a "village" partner than a "governmental" partner. The fact that IBDSP's staff and part of UCLCP's staff are established within villages supported the establishment of good relationships with villagers. By contrast, KRCD staff was located within the strictly protected area, side by side with the officials from the Wildlife Division and TANAPA. Work with communities was mostly carried out by short term consultants and brief visits. Consequently they did not develop long term ties with villagers.

A major factor regarding the perceived success of projects in conflict mitigation from the community point of view is also the type of participation implemented by the projects (Pimbert and Pretty 1997) determining the level of integration of communities' points of view and visions. There seems to be a gradient in the level of participation, KRCD using mostly a passive participation, while UCLCP and IBDSP promoted functional and interactive participation. None of the projects reached the ultimate step of self-mobilization but the participation of beneficiaries in decision making was more developed in the latter.

A key indicator of this project's capacity to be supportive in mitigating conflicts is the fact that-according to the District Executive Director of Mpanda-there is far less complaints from villagers about bad treatments and harassment from the anti-poaching teams.

\section{Factors beyond project influence}

The implementation of community conserved areas and more generally CBNRM projects' results are conditioned by factors that are beyond the influence of projects and relate to power relationships between the state, private stakeholders and local communities, as well as to the context in which devolution processes have taken place. These governance 
problems can hamper the efforts developed by projects in managing conflicts. This is particularly the case with the wildlife management areas' implementation process, which is stalled because of the poor commitment of the Wildlife Division to its own policy regarding community conservation and a poor governance of the wildlife sector (Baldus 2006; Nelson 2007; Nelson et al. 2007). The policy was adopted under donors' influence. As a result, and despite heavy donor investment and support, not a single wildlife management area is fully operating today in Tanzania. And villagers are still waiting to receive the promised return of benefits from hunting (Nelson 2007; Igoe and Croucher 2007). This contributed to an upsurge in conflicts between communities and conservation agents.

One might argue that CBNRM projects are all about influencing institutional change and power relations, but from our point of view this is more achievable by programmes and institutional changes at national levels than by field projects. If large donors like the GTZ or USAID may have a significant influence on the government, considering the importance of the support they are bringing to the country, this is definitely not the case for small NGO's like ADAP. Moreover, to be effective, such institutional changes must be endogenous and not imposed by external stakeholders.

The historical legacy largely explains the current situation, and leads to a situation of privatization of sovereignty (Brockington and Igoe 2006), particularly regarding the trophy hunting activity. Vast tracts of land have been allocated to private foreign companies, privatizing the access and use of the territories and resources as has been observed in other African countries (Roulet 2004). This phenomenon characterized by a relation of mutual dependence between elites - in our case governmental officials in charge of wildlife management and wealthy trans-national networks of professional hunting agenciesensures their exclusive access to- and use of natural resources. It is part of a policy trend exempting the state from its responsibilities, and institutionalizing an indirect form of state control.

Other examples in the Southern African Development Community such as the Namibian Conservancies, reveal that with a real political will and better governance, community based wildlife management areas can generate important benefits to local communities, while contributing significantly to biodiversity conservation (NACSO, 2004). In Tanzania, the resistance of the Wildlife Division to decentralize decision making and economic power largely explains the meagre results, despite the efforts or commitment of project managers to reach their objectives.

\section{Conclusion}

Different lessons can be learned from these experiences for future CBNRM projects and the reconciliation of conflictive stakeholders' interest in conservation.

- Projects should take into account historical context. When adopting an historical approach, the primary causes of conflicts appear more clearly. In the studied case, the crux of the conflict is the opposition between legitimacy and legality of rights over these areas and the resource. The conflict could be labelled as "sense of ownership", as each of the stakeholder claims supposed or alleged rights over the same areas. This probably explains why the issue of the double status of forest reserve and game controlled area is not addressed. Indeed it leaves an open space for every stakeholder to claim its rights. Adopting such an historical approach helps integrating competitive stakeholders' interests into the frame of negotiated solutions. 
- Projects should see conflicts as opportunities. If properly addressed, conflicts can play an important, constructive and structuring role in the establishment of institutional arrangements between stakeholders. In such a context, there is a need of a facilitator, a "bridge-builder". Actors involved in cooperation projects can play this role.

- Projects should integrate the different stakeholders' views in the conception of the projects. Big top-down projects seem less efficient in doing so, compared to small locally adaptive projects. Effective participatory processes help to integrate all stakeholders' views and knowledge systems, to trade off between different management strategies and to reconcile multiple interests in resource management.

- Projects should develop components aiming at supporting the development of alternative sources of income for communities. It appears difficult and probably unethical to strengthen conservation measures in an area, thus restricting local forms of use, without offering alternatives to local communities in terms of revenue generation. By doing so, projects are able to re-equilibrate the cost benefit balance of conservation. This can be done through a system of support to local initiatives that will equally contribute to ensure a better relationship with local communities.

- Projects should adopt a systematic approach of capacity building at local level so as to ensure that in the end communities will be able to manage on their own land and resources, in coordination with public bodies in charge. This capacity building process cannot be done through one time training, but rather implies a continuous process of repeated training and follow up measures, particularly when there are changes in staff among the involved organisations and at village level.

Acknowledgments We thank COSTECH and TAWIRI for permissions at the national level, District and division staffs for their support at local level, the villagers that patiently accepted to answer to our questions. We thank the SDC-KFPE Program and the University of Applied Sciences of Western Switzerland for funding. We thank Fred Nelson, Daniel Brockington, Andrea Finger-Stich, Gilles Forster, Russel Taylor, Emmanuel Torquebiau and an anonymous reviewer for comments on the manuscript.

\section{References}

Adams WM (2004a) Colonialism, hunting and the invention of poaching in the nineteenth and twentieth centuries. In: Borrini-Feyerabend G, MacDonald K, Maffi L (eds) Policy matters, history, culture and conservation, issue 13. CEESP, IUCN, Tehran, Iran, pp 50-60

Adams WM (2004b) Against extinction: the story of conservation. Earthscan, London

Adams WM, Hulme D (2001) Conservation and community: changing narratives, policies and practices in African conservation. In: Hulme D, Murphree M (eds) African wildlife and livelihoods. James Currey, Oxford

Adams WM, Hutton J (2007) People, parks and poverty: political ecology and biodiversity conservation. Conserv Soc 5(2):147-183

Adams WM, Brockington D, Dyson J, Vira B (2003) Managing tragedies: understanding conflicts over common pool resources. Science 302:1915-1916. doi:10.1126/science.1087771

Agrawal A, Gibson C (1999) Enchantment and disenchantment: the role of community in natural resource conservation. World Dev 27(4):629-649. doi:10.1016/S0305-750X(98)00161-2

Alcorn J, Kajuni A, Winterbottom B (2002) Assessment of CBNRM best practices in Tanzania. Final report prepared for USAID Tanzania and USAID Africa Bureau, Office of Sustainable Development

Alden-Wily L (2001) Forest management and democracy in East and Southern Africa: lessons from Tanzania. IIED, Gatekeeper Series, 95, London

ADAP (2002) Inyonga beekeeping development support programme. Villages survey report. Geneva

Austin A, Fischer M, Wils O (eds) (2003) Peace and conflict impact assessment: critical views on theory and practice. Berghof Handbook Dialogue Series $N^{\circ} 1$. Berghof Research Center for Constructive Conflict Management, Berlin 
Balasinorwala T, Kothari A, Goyal M (2004) Participatory conservation: paradigm shifts in international policy. IUCN, Gland, Switzerland and Cambridge, UK, and Kalpavrish (India)

Baldus RD (2006) Tanzania: the crucial role of governance in ecosystem management-conclusions from the selous conservation programme. IUCN SSC Gnusletter 25(2):11-13

Baldus RD, Cauldwell AE (2004) Tourist hunting and its role in the development of wildlife management areas in Tanzania. Game Wild Sci 21(3):591-614

Balmford A, Moore JL, Brooks T, Burgess N, Hansen LA, Williams P, Rahbek C (2001) Conservation conflicts across Africa. Science 291:2616-2619. doi:10.1126/science.291.5513.2616

Mulder MB, Caro T, Msago OA (2007) The role of research in evaluating conservation strategies in Tanzania: the case of the Katavi-Rukwa ecosystem. Conserv Biol 21(3):647-658. doi:10.1111/j.15231739.2007.00703.x

Brockington D (2004) Community conservation, inequality and injustice: myths of power in protected area management. Conserv Soc 2(2):411-432

Brockington D, Igoe J (2006) Eviction for conservation: a global overview. Conserv Soc 4(3):424-470

Bush K (1998) A measure of peace: peace and conflict impact assessment (PCIA) of development projects in conflict zones. Working Paper $\mathrm{N}^{\circ} 1$. The Peacebuilding and Reconstruction Program Initiative and The Evaluation Unit, IDRC, Ottawa

Carpaneto GM, Fusari A (2000) Subsistence hunting and bushmeat exploitation in central western Tanzania. Biodivers Conserv 9:1571-1585. doi:10.1023/A:1008943003752

de Vries D (2005) Choosing your baseline carefully: integrating historical and political ecology in the evaluation of environmental interventions. J Ecol Anthropol 9:35-50

Fitzherbert E, Gardner T, Davenport TRB, Caro T (2006) Butterfly species richness and abundance in the Katavi ecosystem of Western Tanzania. Afr J Ecol 44:353-362. doi:10.1111/j.1365-2028.2006. 00655.x

Gardner TA, Caro T, Fitzherbert E, Banda T, Lalbhai P (2007) Conservation value of multiple-use areas in East Africa. Conserv Biol 21(6):1516-1525

Hausser Y, Mpuya P (2004) Beekeeping in Tanzania: when the bees get out of the woods... An innovative cross sectoral approach to community based natural resource management. Game Wild Sci 21(3):291-312

Hoffmann M (2003) PCIA methodology: evolving art form or practical dead-end? In: Austin A, Fischer M, Wils O (eds) Peace and conflict impact assessment: critical views on theory and practice. Berghof Handbook Dialogue Series $N^{\circ} 1$. Berghof Research Center for Constructive Conflict Management, Berlin

Igoe J, Croucher B (2007) Conservation, commerce, and communities: the story of community-based wildlife management areas in Tanzania's Northern tourist circuit. Conserv Soc 5(4):534-561

Institute of Resource Assessment (2005) An assessment for a community based natural resources management area in Mpanda district-Ugalla ecosystem. Report prepared for AFRICARE. Dar es Salaam

Jambiya G, Jones C, Bakobi B, Kiwango E (2000) Community based conservation (CBC) experience in Tanzania: an assessment of lessons learned. Summary report for EPIQ Tanzania, prepared by International Resource Group, Dar Es Salaam

Jambiya G, Milledge SAH, Matango N (2007) "Night time spinach": conservation and livelihoods implications of wild meat use in refugees situations in north-western Tanzania. TRAFFIC East/Southern Africa, Dar es Salaam

Kajembe GC, Gamassa DGM, Kaale BK (2004) Participatory evaluation report for the Ugalla Community Conservation Project, Tabora, Tanzania. Report prepared for AFRICARE

Mann S (2007) Katavi-Rukwa conservation and development programme-lessons learned. Eco Consulting Sepp \& Busacker Partnerschaft. Deutsche Gesellschaft für Technische Zusammenarbeit (ed), Eschborn, Germany

Matiru V (2000) Conflict and natural resource management. FAO, Roma

Ministry of Natural Resources and Tourism (2000) A study on beekeeping in cross-sectoral areas, national forest programme formulation in Tanzania. Forest and Beekeeping Division, Dar es Salaam

Ministry of Natural Resources and Tourism (2002) Katavi-Rukwa ecosystem management plan. Wildlife Division and Tanzania National Parks, Dar es Salaam

Namibian Association of CBNRM Support Organizations (NACSO) (2004) Namibia's communal conservancies: a review of progress and challenges. NACSO, Windhoek

National Bureau of Statistics (NBS) (2002) Tanzania national census 2002. NBS, Dar es Salaam (census)

Nelson F (2007) Emergent or illusory? Community wildlife management in Tanzania. IIED, Dryland Issue Paper 146, London

Nelson F, Nshala R, Rodgers WA (2007) The evolution and reform of Tanzanian wildlife management. Conserv Soc 5(2):232-261

Neumann R (1998) Imposing wilderness: struggles over livelihood and nature preservation in Africa. University of California Press, Berkeley 
Pimbert MP, Pretty JN (1997) Parks, people and professionals: putting "participation" into protected area management. In: Ghimire KB, Pimbert MP (eds) Social change and conservation: environmental politics and impacts of national parks and protected areas. Earthscan, London

Roulet PA (2004) Chasseur Blanc, cœur noir? La chasse sportive en Afrique centrale. Une analyse de son rôle dans la conservation de la faune sauvage et le développement rural au travers des programmes de gestion de la chasse communautaire. Ph.D. Thesis, Orleans University

Sayer J, Campbell B (2004) The science of sustainable development-local livelihoods and the global environment. Cambridge University Press, New York

TANRIC (1995) Hunting technical services and ministry of natural resources and tourism (1996): physiognomic vegetation map, sheets SB-36-14, SB 36-9, SB-36-10, SB-36-13. National Reconnaissance Level Land Use and Natural Resources Mapping Project. Institute of Resource Assessment (IRA), Dar es Salaam

Walsh MT (2006) Conservation myths, political realities, and the proliferation of protected areas. Conference given at the African Environment Lecture, African Environment Programme, Oxford University Centre for the Environment (OUCE), University of Oxford, 24 November

West P, Igoe J, Brockington D (2006) Parks and peoples: the social impact of protected areas. Annu Rev Anthropol 35:251-277. doi:10.1146/annurev.anthro.35.081705.123308 